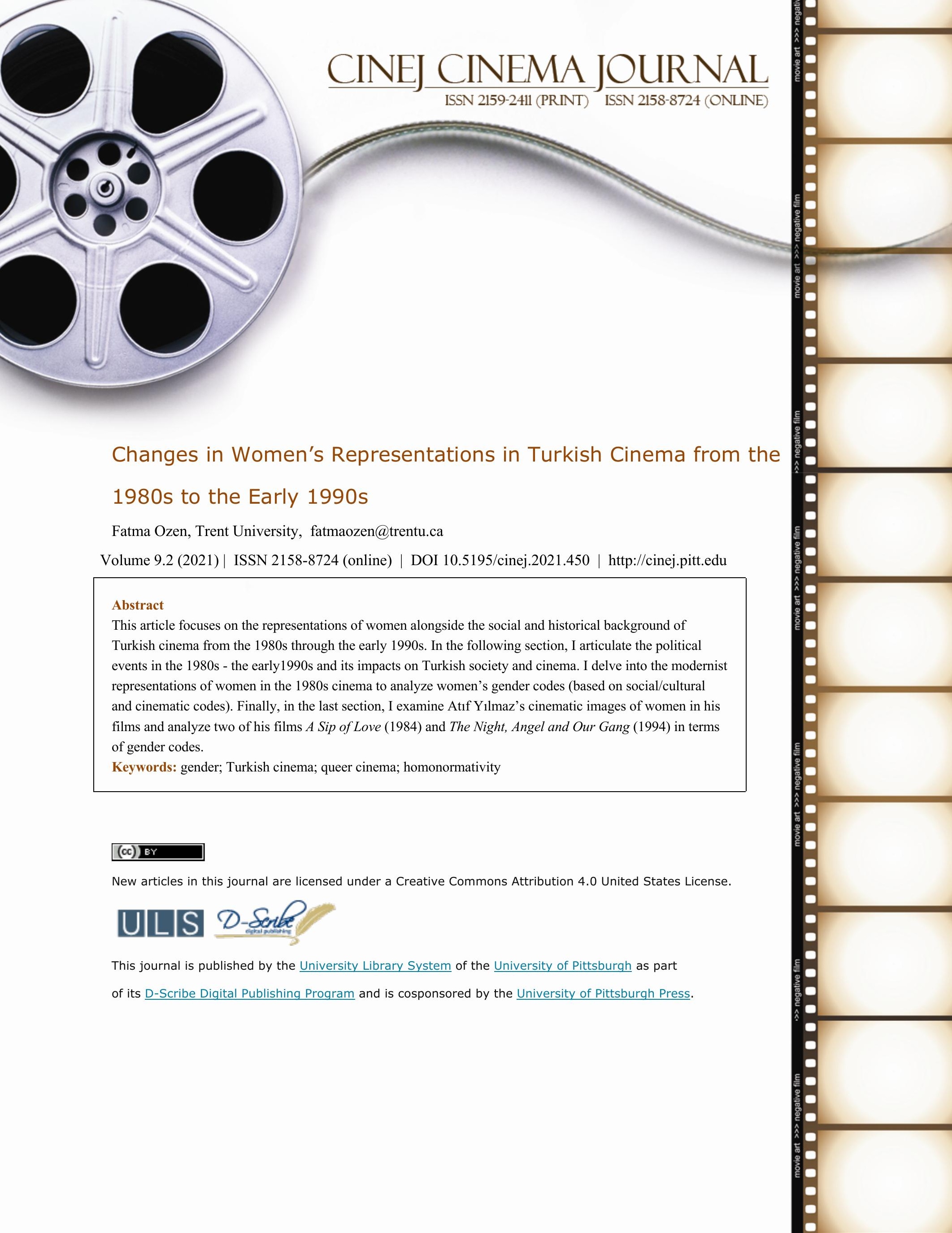




\section{Changes in Women's Representations in Turkish Cinema from the 1980s to the Early 1990s}

Fatma Ozen

Dominant Gender Codes in Turkish Cinema from the Early 1980s through the Early 1990s

In the late 1970s, there was a strong political division between the Right and the Left, resulting in social and political instability in Turkey. To cease political conflicts, the Turkish military launched a coup d'etat on 12 September 1980. With the coup, all the activities of the Left and Right political parties were halted by force, which created a period of depoliticization. As a result, democracy was suspended in the country (Zurcher, 2017). Curfews, murders, tortures, and death sentences were some of the penalties imposed on people, especially those engaged in politics. All the conflicts adversely affected Turkish society, and under the circumstances, people struggled to survive by protecting themselves from the chaotic atmosphere. Although the objective of the military was to end the social and political crises which began in the late 1970s and went through until the 1980s, all these attacks and social effects, which Turkey was going through, left indelible wounds on the society. Hence, the 1980 s were a period that placed the country in a serious dilemma with the effect of an ambivalent and dark atmosphere, full of state prohibitions, censorships, arrests, and tortures (Samim, 1981). 
Following the oppressive social and political climate of the 1980s, the first social movement against the military regime was the women's movement since the Right and Left groups were suppressed and punished by military forces (Arat, 1994). Emerging after the establishment of Turkey in 1923, the women's groups gradually became more independent and powerful in a social milieu. In the 1980s, women believed they could, for the first time, raise their voices and demand their own rights and freedom by gathering groups of like-minded people and organizing campaigns, marches, and demonstrations (Atakav, 2013). Questioning the gender codes in that period, the women's movement challenged the gender identities (Atakav, 2013). While women were still expected to be under male authority, the 1980s became a period that broke down all the patriarchal values and allowed women to raise their voices for their lives - desires, needs, and rights, because until then, their status in the society was generally subdued. Women surrounded by social pressures and values were kept under the control of patriarchy and even were not deemed as an individual in family relationships (Tekeli, 1981). For women who did not want to live under these circumstances and hoped to enjoy their lives with the feeling of freedom, the women's movement was a token of emancipation. Fighting for gender equality and against the patriarchal system, these women succeeded at contributing "significantly to the process of democratization after the military coup" (Atakav, 2013, p.35). 
Throughout the post-coup period, women constituted small communities, which were distinct from the political parties, challenged all the socially and culturally determined values, and discussed other personal issues such as domestic violence (physical and verbal) against women, forced marriage (arranged marriage), sexual assault and harassment (Arat and Pamuk, 2019). Overall, as Atakav (2013) indicates, the women's movement "[was] the first social and political movement to demonstrate the courage to be in opposition and articulate women's issues. In this context, women became able to express and enunciate their concerns and self-understanding" (p.35).All these struggles, consequently, provided women to acquire a more democratic and liberal milieu with new opportunities.

Among those most affected by the chaotic atmosphere were women who were in search of their identity and freedom with their rights. Likewise, in the 1980s, Turkish cinema showed some changes under the social and political conditions in the country. Among these shifts were the representations of women and their issues that filmmakers aimed to display in their films. At that time, social and political films were forbidden and censored. Therefore, the filmmakers avoided narrating social and political issues for fear of punishment and censorship (Atakav, 2013). The shifts in women's representations and the emergence of women's films in Turkish cinema were the result of social and political conditions in the $1980 \mathrm{~s}$. 
With the depoliticization of the 1980 s, filmmakers attempted to focus on particularly women and their social issues, which could be said to be in the same period as the women's movement. As well as women's films, the pornographic films of the 1970s were replaced with arabesque-themed films ${ }^{1}$ in the 1980s (Akser, 2018). Women's status and roles in social life were transferred to the cinema. Along with the positive effects of the women's movement, the 1980s paved the way for distinctive changes in the cinema. Put differently, women gained individuality and a modernist perspective in the cinema. They were depicted as independent, self-assured, sophisticated, and unconventional beyond the binary oppositions (morally good vs bad) (Atakav, 2013).

The wave of feminism in the 1980s was highly influential in Turkey and inevitably in Turkish cinema. One of the most visible reasons that the 1980s cinema differed from that of previous years was the changes of the binary oppositions in terms of the representations of women - that is, the emergence of individual and complex characters (from one-dimensional to multidimensional) explicitly proved this progressive form. Thus, women's roles and rights were critically discussed in the cinema (Donmez-Colin, 2010). According to Atakav's (2013) view on the new portrayal of women, the cinema gave a new identity to women, liberating them from conventional characteristics offered by patriarchy. In this sense, they turned into more complicated 
and emotionally deep characters. Furthermore, Atakav (2013) implies the main reason for the conventional characterization stems from a feudal ideology that is rather relevant to the patriarchal dominance.

For the first time, women in the 1980s cinema were able to acquire independence in their sexuality and social life. While the image of a naive, illiterate, and domesticated woman was dominant in the years before the 1980 s, to see the image of a free woman breaking down all the opposite rules was quite shocking in the cinematic perception. It would not be wrong to state that the unconventional representations of women were constructed through Western ideologies. As a result, Turkey, which was influenced by not only the feminist movements in the West but also the Western narrative styles and representations, was exposed to highly harsh critiques by people who did not adopt the Western ways of life. One of its most crucial reasons was that the family structure in films was ignored by women, which was a push against traditional cinema before the 1980s. In relation to this issue, Dönmez-Colin (2004) summarizes "Women were no longer the founding stone of the family, bearing the burden of keeping it together, but independent beings trying to find solutions to personal problems"(p. 57).

In the 1980 s cinema, women were portrayed in various ways - such as vamp, whore, and femme fatale (mysterious and seductive woman). Along with these representations, eroticism, nudity, and sexuality were brought to the fore in the cinema (Duyan, 2013). However, in general, 
women's representations in the cinema are split into two categories: bad women as evil-mannered and femme fatale and domestic women who are classified as an innocent lady, a good wife and mother and mostly are in working and middle class, dependent on men and have traditional values. In one sense, in terms of their roles in films, they are assessed as positive or negative, depending upon the constructed patriarchal criteria (Kaplan, 2001). In each decade of the cinema, these two categories alter according to the socio-cultural values and patriarchal discourses that function to position "women as silent, absent, and marginal" (Kaplan, 2001, p. 34). Despite all these alterations (from innocent to masculine women or from secular and independent to conservative and absent women) the cinematic portraits of women present more or less the similar visual perceptions to viewers and are embedded as gender codes into films. By deconstructing these codes, it is possible to capture meanings that the cinematic language produces.

There was another shift from the late 1980s through the 1990s. Islamic movements gained more visibility in Turkey and became influential in politics. The number of women who defended Islamic values and evoked the movement of Islamic feminism ${ }^{2}$ steadily increased. This time, women questioned the importance of women in Islam (Leake, 2011), and instead of their sexual freedom, they grounded claims on their religious rights and freedom. There were the vast majority of reformist feminists who believed that the headscarf gives their freedom in contrast to those who 
believed that it is a symbol of bigotry (Leake, 2011). For them, the image of woman depicted as a sexual object is, in fact, what men create in a male-dominated society, and this depiction is opposite to moral and religious rules. Therefore, women - known as Islamist feminists - intended to change this sexual perception imposed on women in every aspect of life.

In the period of the 1990s, Turkish cinema had various representations of women, but it was also influenced by the Islamic perspective in a certain sense. The cinema of that period was called "white cinema" in which the representations of women were completely shown within the frame of Islamic rules (Kaya and Azak, 2015). As Dönmez-Colin (2004) argues in her book, "women's place (or lack of it) in the cinemas of the Islamic countries is directly linked to social and political evolutions in which religion and religious customs play an important role" (p.7). As different from the liberal cinematic perception of the 1980s, the 1990s were a period when women were represented as beings who are away from their sexuality and are obliged to live in moral and religious rules. In relation to this matter, a scholar claims, "the language of the body is the language of Islam" (Dönmez-Colin, 2004, p.14).

Unlike the abovementioned approaches, Atıf Yllmaz chooses not to apply Islamic and patriarchal perspectives to cinema, He portrays women from an anti-patriarchal perspective and discusses women's search for identity through their sexuality and sexual freedom. His approach 
to women makes him gain distinctive acclaim in the history of Turkish cinema. In the next section,

I examine his cinematic language, and the modernist portrayals of women in his films.

Atıf Yılmaz's Approach to Women in Cinema and The Representations of Women in His

Films

In the 1980s Turkish cinema, Atıf Y1lmaz is "the first filmmaker to approach the sexuality

of the new women in a positive manner and to create independent women characters" (Dönmez-

Colin, 2004, p. 138). In fact, this modernist approach enables him to construct a different cinematic

language from the other filmmakers of the period. Although women's representations were

exhibited as modern, independent, and secular in years before the 1980s, patriarchy dominated

these representations, which caused women to be displayed as partly independent (Kilickiran,

1997). That is, women can have the right to speak and have social responsibilities, however they

have to obey patriarchal rules in their daily lives. As different from women's representations before

the 1980s, Atıf Y1lmaz focuses on the conception of powerful and invincible women in his films.

In working on his films, he always intends to place women at the center.

Cinema is the voice of society and is shaped through the social, cultural, and political conditions in the country. Thus, cinema presents deep narratives through films. As part of society, women are rather suitable for reflecting this depth through their visual presence because they 
mostly internalize their emotions and issues (under the patriarchal pressure) and are good at dealing with all the emotions and problems, which turns them into complex and intriguing characters. Thus, through the representation of women, Yilmaz attempts to question the conditions and dilemma women live in, raising some questions: "Who are they? Why do not they have as many rights as men have? If they do not have the right to speak up, then why do they live? For men or themselves? If they do for themselves, why do they have to obey the patriarchal rules?

When the 1980s Turkish cinema is closely examined on the basis of not only women but also their gendered codes, we can discern that Atıf Yılmaz, as distinctive from other filmmakers of the period, brings a deeper perspective to the cinema regarding the concept of woman. In his films, he draws upon unconventional portrayals of women - prostitutes, small-town women, ordinary housewives, and actresses - who are fully aware of their sexuality. Their struggles they have for the sake of their sexual needs and desires are always awarded at the end of the film, which is one of the prominent steps Atıf Yllmaz takes for his characters, as separated from the characters in other filmmakers' films (Dönmez-Colin, 2004). Also, in his films, he posits eroticism at the forefront, considering that it allows women to get to know themselves and be aware of their sexual needs. Through his cinematic language, the modernist representations of women are viewed in his major films: Mine (1983), A Sip of Love/ Bir Yudum Sevgi (1984), A Widow/ Dul Bir Kadın (1985), 
Her Name is Vasfiye/ Adı Vasfiye (1985), How Can Asiye Be Saved? /Asiye Nasll Kurtulur? (1986)

and The Night, Angel and Our Gang/Gece, Melek ve Bizim Çocuklar (1994) (Cengiz, 2020).

In the following section, two of his significant films, A Sip of Love (1984) and The Night,

Angel and Our Gang (1994), are critically analyzed in terms of the representations of women and the discursive effects of society on the establishment of women's gender codes. While the films are being analyzed, the cinematic and narrative techniques, as semiotic codes, are taken into consideration alongside the social and political conditions of the period, inasmuch as all these forms develop the way in which women are displayed on the silver screen, thereby engendering the specific representations of women.

A Sip of Lovel Bir Yudum Sevgi (1984)

A Sip of Love revolves around the story of women who are suppressed by male domination and search for their own independent choices and desires in their lives. As its name suggests, these women look for love in their loveless and unhappy marriages, no matter where they live or what conditions they have. Also, the film explores how significant the sexuality and the power of love are in a marriage, with "the evolution of women in a society that is in transition" (Dönmez-Colin, 2004, p. 137). 
A Sip of Love, in which Atıf Y1lmaz displays women's resistance against patriarchy and its traditional values, is among his well-known films in terms of discussing specifically women's issues. While he focuses on only the main female character throughout the film, he does not ignore other women in the narrative, and places them in various roles. In terms of gender codes, the film presents many analytical aspects (questioning the place of women, moral and conventional values in society) to spectators regarding women and leaves the door open to raise awareness of women's issues. Thus, it is possible to examine the film in depth, considering women's representations via semiotic codes (social/cultural codes) and other cinematic techniques (cinematic codes), such as characterization, the plot, camera movements and angles, lighting, and the framing of cinematic images, as well as their resistance and importance in a male-dominated society.

The heroine of the film, Aygül (Hale Soygazi) is a woman who gets stuck in an unhappy marriage with four children. Despite the dilemmas she is in, she is determined to challenge patriarchy and its social pressures so as to pursue her desires. In this respect, she is displayed as an independent, fearless, and strong woman throughout the film. For her, the sole solution to escape from this unaffectionate marriage is to love another man. Cemal (Kadir Inanir) is a goodlooking married man with a kid and likewise, stuck in a forced marriage. Instead of escaping from this marriage, he chooses to satisfy himself with another woman, yet as the film continues, we can see that Cemal surrenders himself to true love - Aygül. Aygül's husband, Cuma (Macit Koper) is 
an unemployed, lazy, passive, mostly drunk, and useless man who spends most of his time sitting in a coffeehouse (kahvehane).

The film begins with a scene in which a group of women, including Aygül living in the slums of Istanbul, listen to a coquettish woman's advice as to how to seduce their husbands and to become a sexy and good partner in bed. Determined to perform what she learns, Aygül tries to sexually persuade her husband after he comes back home; however, his reckless behaviours discourage her. For Aygül, the conditions she lives in, and her marriage are nothing more than hell. To elude the pressures of her marriage and poverty, she wants to work, hoping that she can have social and financial independence, and finds a job in the factory with the help of Cemal. The friendship between them gradually turns into love, although they both are married. At the end of the film, despite all the traditional and moral values in the eyes of society, they show they can overcome all difficulties with the power of true love.

A Sip of Love is a classic film that narrates ordinary people, yet what makes it interesting is how Atıf Yilmaz displays women through various representations in the film and even unabashedly features their sexual demands. As noted earlier, there are several women who have divergent characteristics - no matter how different they appear at first, they all complain about the lack of sexuality - in the social structure. Hence, the aim of textual analysis is to examine not only 
the main character Aygül but also other female characters shaping the film in terms of the social conditions of the country and semiotic codes.

As a representation of independent women of the 1980s, Aygül portrays a modern and liberal image. We explicitly observe that throughout the film, Aygül constantly disdains her husband as he does not work and dawdles on the streets all day, instead of looking for a job. With Aygül finding a job, her life and status in the family completely changes - from a woman expecting her husband to work and bring money to a woman earning her own money and ignoring her husband. "As women shoulder additional responsibilities connected with the social status of the family in the 1980s Turkey, they appear to take over from men the capacity to act as family representative" (Özbay, 1995, p. 109). As seen in the film, Aygül's behaviours have dramatically altered shortly after she begins to work in the factory. Taking over the responsibilities her husband must have, Aygül both challenges male domination as the breadwinner of the family and breaks down the prejudices that married women should not work, as other women working in the factory do. What's more, Özbay (1995) points out "the relations of sovereignty in the framework of gender in the family and in society are so deep that the changes observed in the activities and status of women can only take place within this framework" (p.109). Likewise, Aygül's relations with her husband show her authority in the family, thereby allowing her to gain a dominant identity beyond the traditional values of the society pertaining to gender identities. 
In his writings, Foucault (1980) states that "mastery and awareness of one's own body can be acquired only through the effect of an investment of power in the body" (p.56). When his statement is taken into consideration in the context of the film, that Aygül is aware of her body and sexuality enables her to gain power in a male-dominated society. That is, she notices that she can overcome the patriarchal power through her own sexuality. Thus, by employing her femininity, she manages to draw Cemal's attention, and thanks to him, she has a job. Unlike that, the power she implements for her husband mostly involves verbal dominance-malediction, humiliation, and insult.

When the character of Aygül is analyzed, Aygül exhibits her gendered characteristics. The language she employs throughout the film is one of her featured characteristics - abusive language and insulting attitude to men - and there are a few scenes highlighting what kind of woman she is through the verbal codes (the subcode of social codes) she uses. For example, in the scene where Aygül walks away from home due to her husband's irresponsible behavior, when her husband, brother-in-law, and sister-in-law come to convince her to come back home, they argue, and she tells her husband, "I am fed up with you and cannot endure such a life. I will never be your wife anymore and will file for a divorce." 


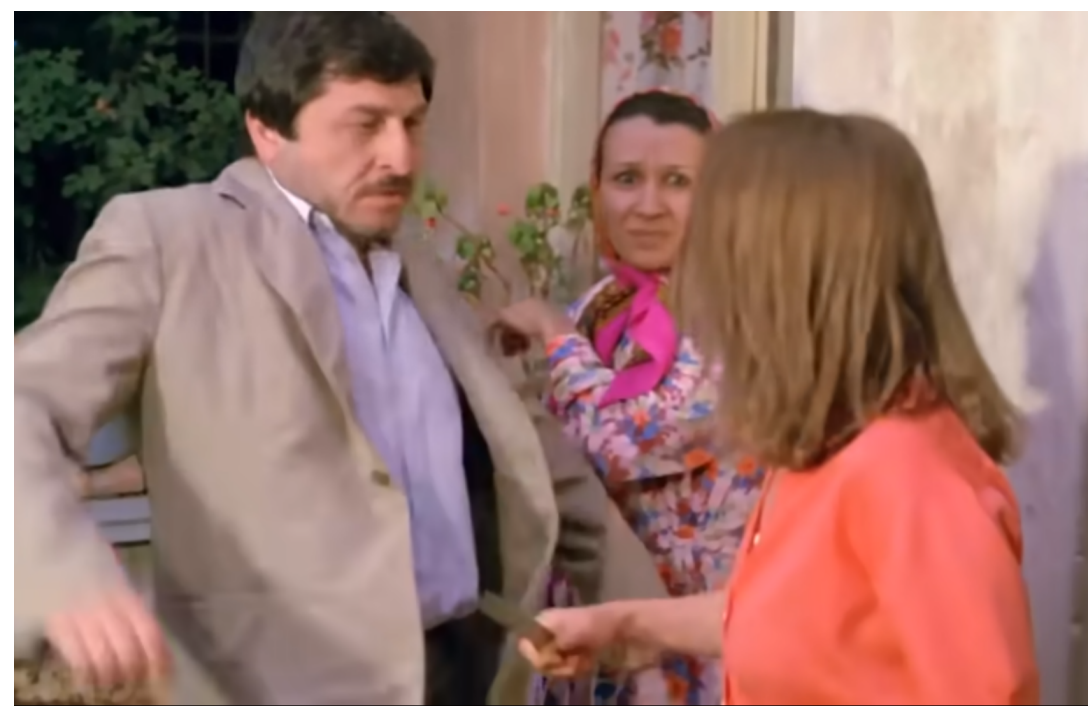

Figure 1: Aygül (Hale Soygazi) attacks her brother-in-law and sister-in-law

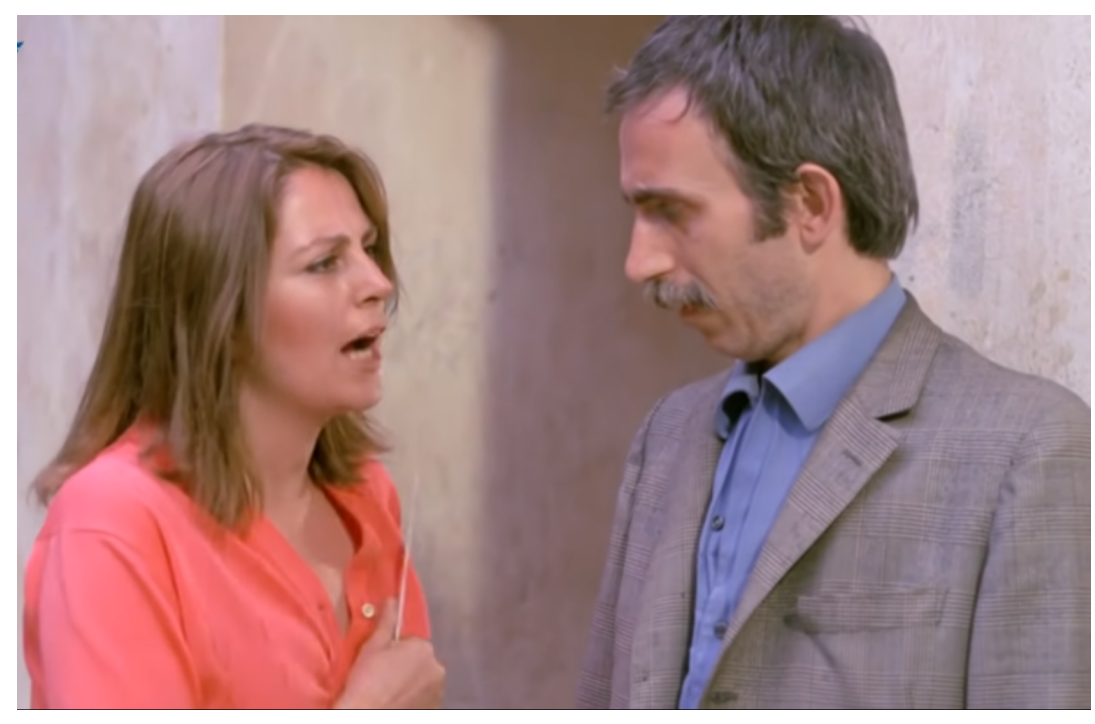

Figure 2: Aygül reprimands his husband (Macit Koper), saying she wants to divorce him

Here, it is rather clear to see how determined Aygül is to gain her social life and sexual desires. In another scene where Aygül and Cemal confess their love, she says, "aside from you, no one else can seduce me." Irrespective of the social criticism and moral values, she chooses the life she wants to live in, which is what women strived to have in the 1980s. In addition to the verbal codes 
Aygül draws on, the bodily codes alike reveal her personality and desires. While she displays indifferent and weary treatment of her husband, her flirtatious gaze and approach, towards Cemal uncover her intentions.

One of the other female characters in the film is Aygül's neighbor Hanife. She draws an image that is more obedient, dependent on her husband, but among women, she seems rather hyperactive and talkative. Indeed, this representation of the woman demonstrates how much women are generally forced to obey men by the socially established values of patriarchy. Regardless of their pent-up demands and sexual desires, they are silenced and exploited by men. Similarly, Cemal's mother and wife carry the same characteristics as Hanife, yet they as separated from Hanife symbolize the other face of Turkey - that is, they live within Islamic rules and judge other women, as unvirtuous and fallen women, outside their worldview. Highly illiterate, religious, and conservative, these two women believe in spells, hoping that Cemal will stop seeing other women and coming back to his wife, which indirectly reflects the dark side of the society. In brief, they are the cinematic reflections of submissive women under male authority.

In the film, the other characters - her lover Cemal and husband Cuma - are highly effective in constructing Aygül's social representation. The former is the epitome of patriarchy. Although tough and indifferent in his family and the neighborhood, he turns into quite a helpful and lovable 
man with Aygül. Even in the neighborhood, no one can dare to judge Cemal although he is known to cheat on his wife and flirt with Aygül. Therefore, Atıf Y1lmaz attempts to create the perception of a Westernized society by going beyond moral and religious rules. With his submissive and cowardly behaviours, the latter is totally opposite to Cemal. Traditionally, in Turkish cinema, it is nearly impossible to see such submissive and inferior male characters like Cuma. However, when this representation is thought in terms of Y1lmaz's cinematic approach to women, it makes sense that he intentionally constructs hierarchical inequality while glorifying women and placing them at the center of the film. Despite all these unusual characteristics of Aygül in the film, she is still a victim of patriarchy. No matter what social issues Aygül challenges, she is verbally sexualized by men who work in the factory, the photographer who takes Aygül's photos, and even the religion teacher (din hocas1), and is exposed to sexual harassment through the male gaze.

While the representations of characters and narrative style were drastically changing in the 1980s, the cinematic techniques and codes continued to be traditionally employed (Atakav, 2013). In addition to the representations of the characters (particularly that of Aygül) analyzed by social codes, cinematic codes have great importance in reflecting the representation of the characters in a particular manner. As such, the representations of women, focusing mainly on Aygül, are critically examined through the cinematic codes to be able to understand Y1lmaz's cinematic language in his films. 
Shots, as one of the cinematic codes ${ }^{4}$, gain crucial functionality in this film. At the beginning of the film, there is a scene where Aygül looks at herself in the mirror, and at that moment, the camera is zooming in on her face through a close-up shot. There is, for the first time, the moment that she notices her sexuality and beauty.

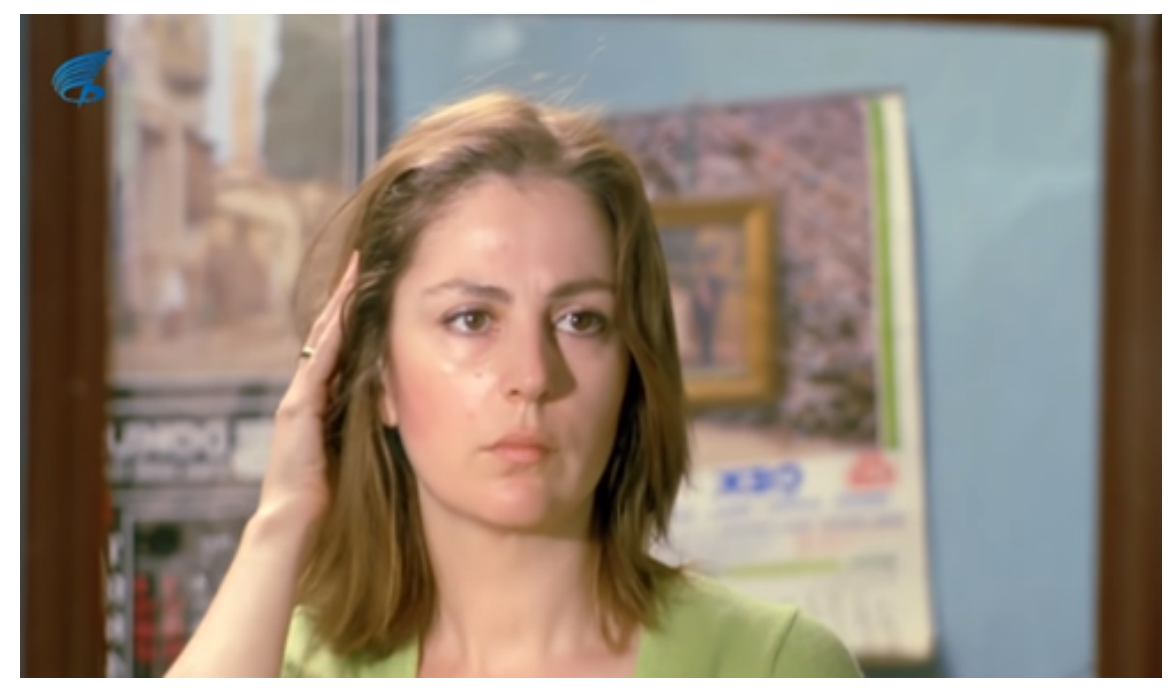

Figure 3: Aygül looks in the mirror

Following this scene, she tries to seduce her husband, wearing sexy lingerie and posing invitingly for him. The main objective of this close-up shot is to raise awareness of her sexual power. The scene where Hanife and Aygül tickle and touch each other is also quite thought-provoking in terms of why the filmmaker wants to use this kind of scene. According to some scholars' views, Atıf 
Y1lmaz probably encourages spectators to get used to sexuality and nudity that will be shown in his next films.

Gaze is generally among the subcodes of the social $\operatorname{codes}^{5}$, yet it gains a cinematic function by way of camera angles and is deemed as a cinematic code. In the film, there are two specific scenes that can be specified to analyze "gaze": the one where Aygül and Hanife watch Cemal playing soccer while passing by the factory and the one where Aygül alike watches him playing soccer while eating an apple at lunch break.

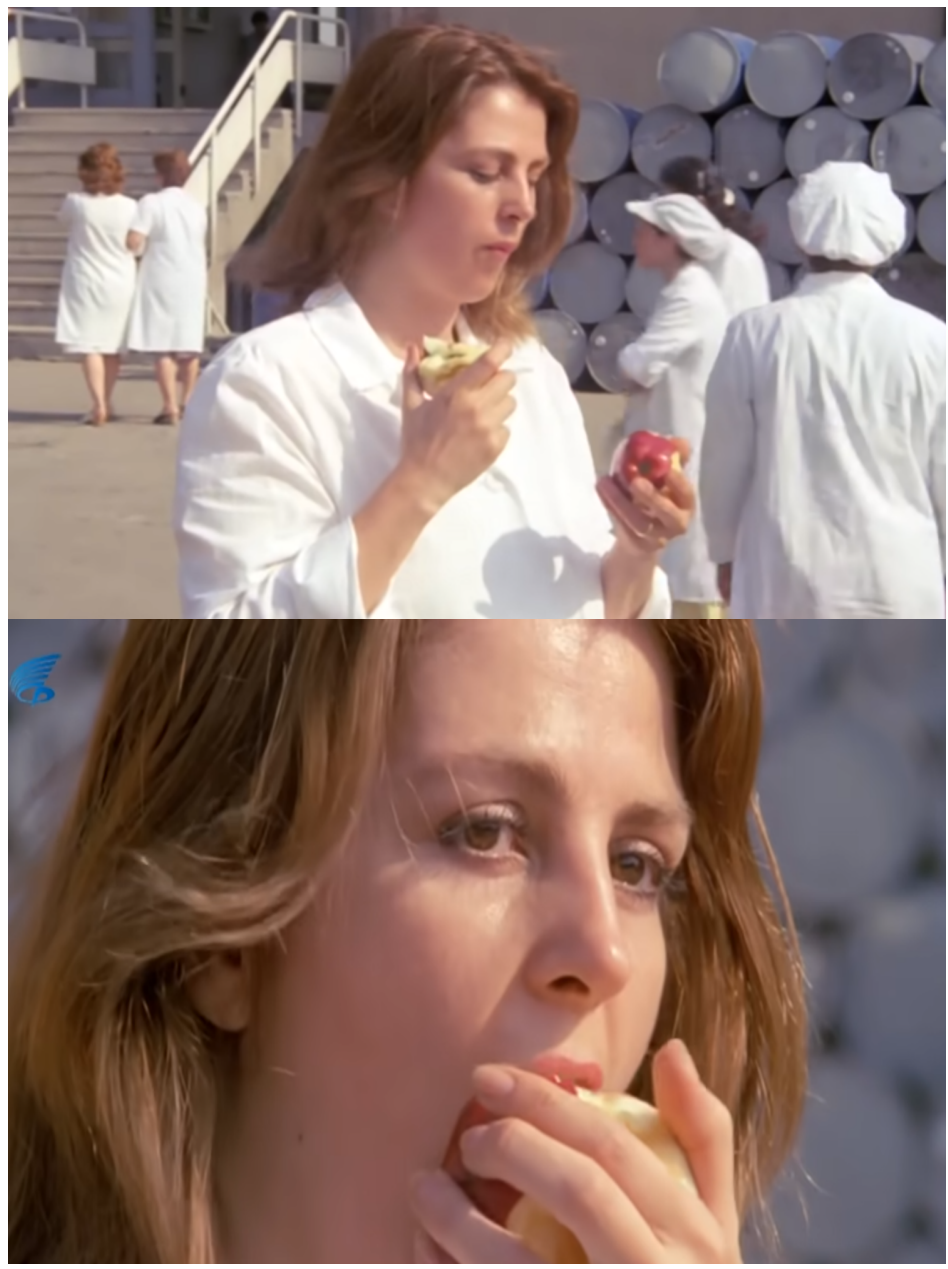

Figure 4-5: Aygül eats Cemal's apple while he plays football 
In these two scenes, women's gaze has sexual meaning through cinematic shots. In the scene where Cemal leaves his apple to her in order to play soccer, Aygül takes his apple and bites it, just like making love with him. Here, the close-up shot on Aygül's face implicitly heralds that a relationship between the two will arise. The male gaze is similarly ubiquitous throughout the film. Due to her beauty and daring behaviours, Aygül is constantly exposed to the male gaze with verbal abuse by men in the neighbourhood, even if she copes with all the abuse, ignoring what she hears from them. In relation to this argument, Foucault (1980) states that "there is no need for arms, physical violence, material constraints. Just a gaze. ... The gaze has had great importance among the techniques of power developed in the modern era" (p.155). Through the male gaze as part of masculine power, men control and try to dominate women, which proves the notion that women cannot escape from the effects of patriarchy and male domination. As in this film, the way in which men look at Aygül serves to establish sexual dominance over her.

In the 1980s cinema, the emancipatory struggles of women, unfortunately, result in either accepting suppression or finding another man. As demonstrated in this film, Aygül chooses Cemal as a solution to escape from her unhappy marriage and to have her own freedom; however, she is unwittingly trapped in a male-dominated structure. Overall, Aygül is "neither the gullible virgin 
nor the sinful prostitute. She is a human being with a right to her sexuality" (Dönmez-Colin, 2004, p. 139).

Some visual images signify meanings within terms of semiotics. Especially diverse tapestries used at the opening scene of the film connotate what the story is about. Similarly, at the end of the film, several marriage photos are shown. In these pictures shown one after other, when attention is paid on Aygül's and Cemal's faces, Cemal turns into a depressed and oppressed man whereas Aygül displays a stronger and assertive pose as the number of their children increases. Taken together, it shows that Aygül acquires an authoritative power in the family through her sexuality.

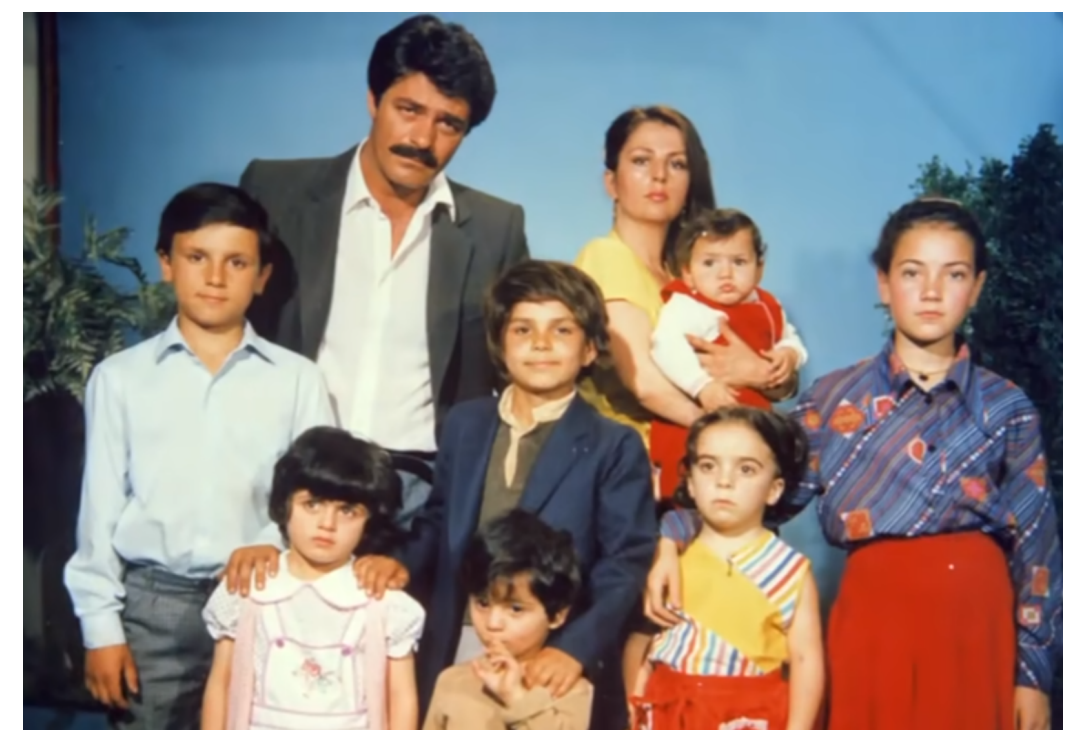

Figure 6: At the end of the film, Cemal (Kadir Inanir) and Aygül (Hale Soygazi) get married

The film generally consists of medium and close-up shots as there are long dialogues between characters and romantic intimacy between the two main characters; nonetheless, in some 
scenes where the neighbourhood and a majority of people are exhibited, the wide shots also exist.

Aside from these camera shots, the other cinematic techniques - lighting, editing, narrative structure, sound, and any other cinematic styles - remain the same as that of the cinema before the 1980s. That is, in the films of that period, daylighting and outdoor shooting are quite prevalent. The narrative structure usually traces a linear and continuous time frame, and sound is effectively used at times as the narrative progresses.

In the next section, another film of Atıf Yilmaz is discussed. In the film shot in the early 1990s, Atıf Yilmaz attempts to represent people excluded from the society where they live, especially the representations of women are separated from his former approach; namely, this time, the images of invisible and unrepresentable women come to the fore.

\section{The Night, Angel and Our Gang/Gece, Melek ve Bizim Çocuklar (1994)}

From the late 1980 s through the early 1990 s, it is possible to discern that the representations of women began to shift again. However, this time, this change tends to be more conservative and constructs a perception of independent but an unvirtuous and outcast woman in the 1990s films. The characteristics of marginalized people and narration play a key role in depicting women within such a specific framework. Throughout the film, there exist violence-oriented scenes and the use of slang words by prostitutes, and trans-people (Erdem, 2019). 
The Night, Angel and Our Gang narrates the story that is about sex workers dwelling on the backstreets of Beyoğlu ${ }^{6}$ and their way of life. The main character Serap (Derya Arbaş) is indeed one of them. Seemingly, she is an independent, strong, and vivacious woman - as understood through her dressing style and behaviour -, yet all alone in her inner world, and this solitude inwardly affects her personality. For her, the only thing she can hold on to is the money she earns by prostituting herself, and the idea that she will become wealthy in the future. Arif, also known as Fulya, is a transgender sex worker. Like Serap, she is alone and as a person coming from a small city of Turkey, looks for people with whom she can get along and trust in her life. Hakan (Uzay Hepar1) is Serap's temporary boyfriend. Even though he falls in love with her, Serap learns that he is a bisexual who has some difficulties with his sexuality after she catches him having sex with another man. Melek (Deniz Türkali) is an ex-sex worker. She once stabbed her lover with jealousy and was imprisoned, but now she is released. The common point of all these characters is that they are all alone and socially outcast from society.

At the beginning of the film, there are a number of pictures in which sex workers, transpeople, and nightclubs are illustrated with screams and siren sounds in the background. Fulya and Serap cross paths at a night raid that the police organize to catch sex workers and transvestites. Fulya has neither money nor a place to stay; therefore, she asks for Serap's help, and Serap allows Fulya to stay at her home. While going to bed, she sees Serap hiding her money, and in the 
morning, she escapes with it. Serap then sees and confronts Fulya in the nightclub. Encountering another police raid, Fulya rescues Serap. They compromise and begin living together. On the same day, Serap meets Hakan while dancing in the nightclub. A few days later, Fulya sees Melek fighting bodyguards waiting in front of the nightclub while passing by and brings her to Serap's home. Likewise, Melek gets out of jail with nowhere to go. Hence, they all take refuge in the same place. After a while, Serap and Hakan fall in love, and he begins bargaining with the men Serap will sleep with, yet he fails. Even when having a relationship with Serap, Hakan keeps seeing his boyfriend. Later on, his bisexuality comes to light when Serap catches them in her bed. Leaving everything behind, Serap goes to Adana $^{7}$ to become a singer with the dream of having a rich lifestyle. As for Melek, she cannot give up wanting her lover Osman so much that in the end, she stabs herself with Osman's knife. At the end of the film, Serap, whose dreams come true as a rich woman, throws a birthday party at the hotel where she has been with her customer.

Fundamentally, the analysis of this film focuses on two characters: Serap and Melek, who differ from each other as they represent two different kinds of women in the 1990s cinema. While the former is stubborn and progressive, the latter is quite submissive and oppressed. At times, other characters will also be mentioned since they interact with Serap and Melek throughout the film and indirectly contribute their representations. 
Serap is seemingly an independent, unsubmissive woman refusing to obey traditional and moral rules.

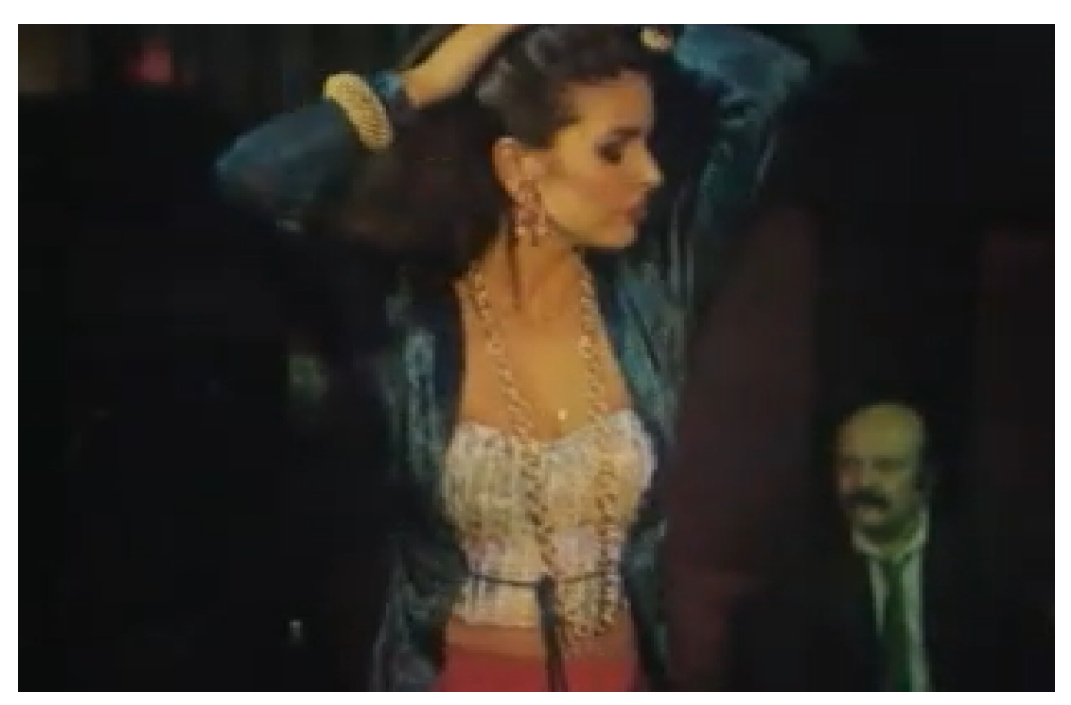

Figure 7: Serap (Derya Arbaş) dances for the man

Making ends meet by prostituting herself, Serap does not have any expectations except for saving money and becoming a wealthy woman. Moreover, Serap is not compelled to prostitute as a reluctant choice; rather, she eagerly prefers to become a prostitute for money and her dreams. On becoming a wealthy woman, she thinks that she can acquire decent respect in society even though she knowingly sells her body (Akser, 2016). She, in this sense, draws an unusual image in the eye of spectators. Similar to other female characters in the 1980s, she is daring and fearless in terms of heteronormative expectations - women should get married and have a husband and challenges the patriarchal rules. This representation of the character is opposite to the image of woman beginning in the 1990s, when Islamic feminism gradually rose and feminine qualities were determined by religious and moral discourses. Throughout the film, Serap implicitly indicates her 
gendered characteristics through social codes. In the scene where Serap sits with Hakan at the seaside, she says, "Are you kidding me? I made this choice not to marry as everyone gets married" when Hakan suggests marriage. Thus, it is easily understood that she goes beyond social norms, breaking down all the dominant discourses - patriarchy and religion. Besides, her dressing style becomes effective in revealing her personality. Due to her job, she puts on flashy and sexy dresses, huge jewellery (fake), and heavy make-up; nonetheless, the choice of colour and style somewhat gives some messages on what sort of personality she has. Associated with passion, power, desire, and determination, the colour red is frequently used on Serap's clothes and it might be interpreted to symbolize Serap's invincible and rebellious characteristic.

In the film, the way Serap speaks is also examined through verbal codes. As a token of power and verbal resistance to men, she continually swears. In the scene where Hakan slaps her, saying that she is a slut, Serap alike counteracts him, employing the words such as "slut," "pimp," "penniless," "motherfucker," and "son of a bitch," instead of physical violence and adds, "No one can slap me!". More to the point, the language she uses is not naive since it is a systematic tool that is ascribed meanings through the dominant ideologies and plays a key role in maintaining the meanings. In addition, her relation to money is clarified through what she says. Especially while counting money, she often repeats, "I will have money, I will have more money, I will have more 
money." Money is the symbol of capitalist power, and, in this sense, it is directly tied to male domination which she tries to free herself from. Given the scene in the film, Serap turns into a part of her ambitions and is considered a victim of male domination. With the money she earns by selling her body to men, she seeks to gain a seat for herself in society. Money, in one sense, is equivalent to her power.
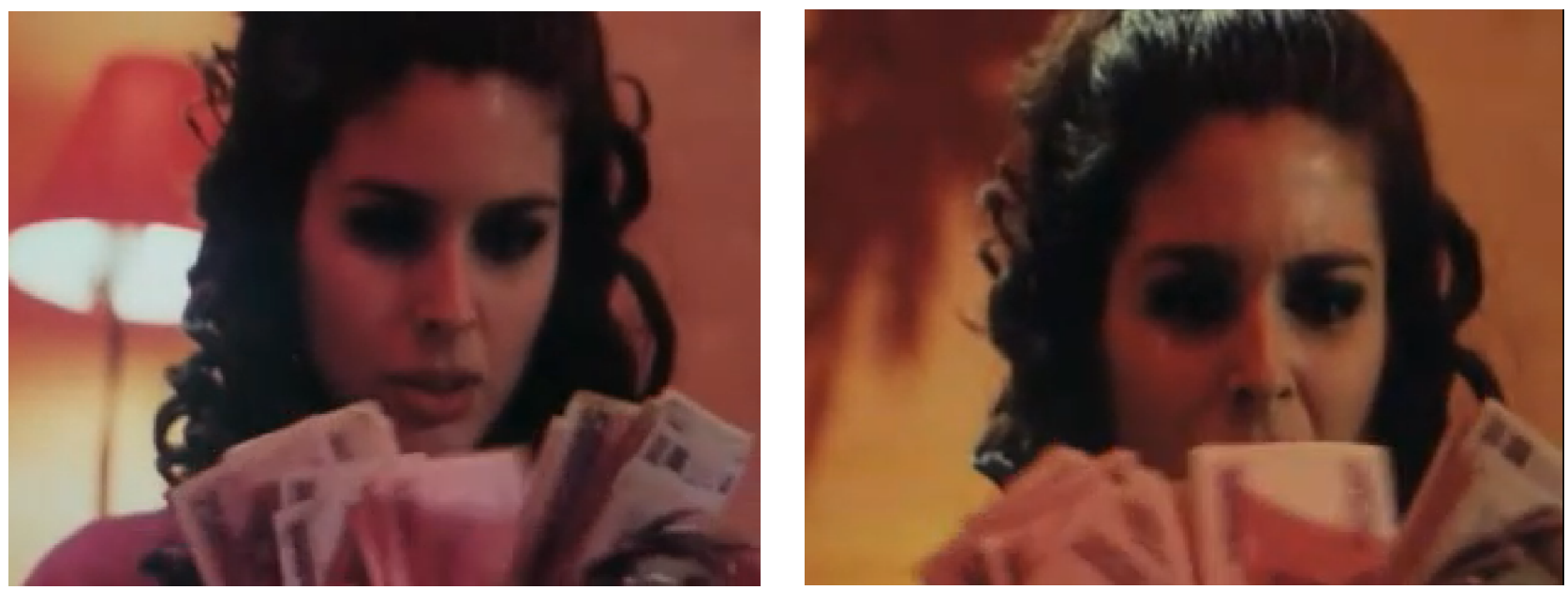

Figure 8-9: Serap ambitiously counts money she earns

As for Melek, she is portrayed as an oppressed and desperate character. After getting out of jail, she knocks at Osman's door but is expelled by his bodyguards every time. She, so to speak, is a representation of desperation and destitution. 


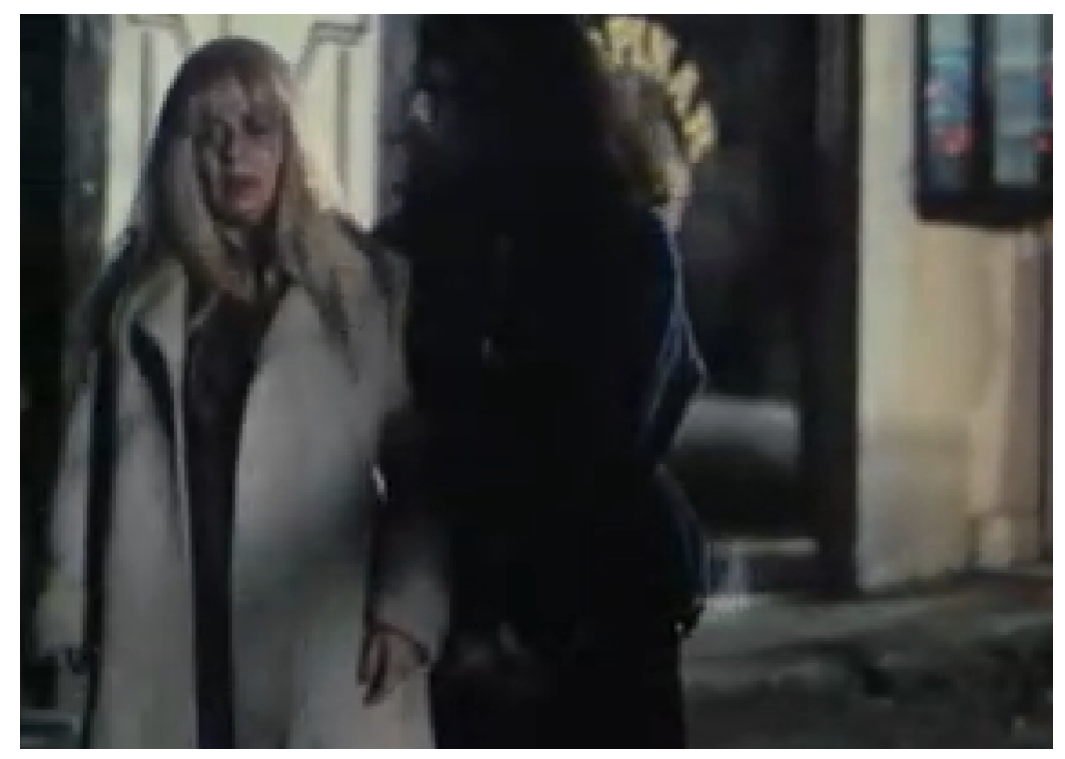

Figure 10: Melek (Deniz Türkali) is desperate after she argues with her ex-boyfriend

More broadly, she bears some similarities to the representations of women in the years before the 1980s, considering the fact that she is exploited and suppressed by a man. As mentioned earlier, bodily codes occupy a pivotal role in signifying the characteristics of a person. As Roland Barthes states regarding codes, what you have and perform is indeed what you sell in society (Berger, 2020). In other words, through the way we act, the clothes we wear, and the way we behave, we construct meanings in society and transfer what we produce to others. In the film, Melek's hair could be analyzed in this context. Although her blond hair is part of her past as a sex worker and Melek intends to change herself, she cannot get rid of her past and continues repeating her mistakes. In the scene where she goes to her old friend's house, thinking that her friend could help her find a job that would change her life, she is, for the first time, seen to veil her hair. For her, it 
is the first step to begin a new life with different hopes. However, she is exposed to serious criticism about her choices and must-have responsibilities (social responsibilities) in life from her friend's son-in-law. Following that, she leaves home and never covers her hair again, returning to her old self drinking and going back to Osman.

In the scene where Melek is raped by a group of alcoholics, the vulnerability of the woman is criticized. As Wittig (1992) argues in her book, "being murdered, mutilated, physically and mentally tortured and abused, being raped, being battered, and being forced to marry is the fate of women" (p. 3). Hence, taken into consideration as a social code, rape is an attack on a woman's sexuality and the war of existence between man and woman because what makes a woman a woman is the gender she has. Therefore, rape is a male desire based on the suppression of a woman. Also, it is a physically-oriented show of strength for men, just like the way they use their social power imposed on women through patriarchy. In relation to the film, that Melek is subjected to rape damages her gender identity as a woman. Although for a while, she seems to have recovered, she mentally deteriorates shortly after Serap leaves for Adana, and at the end of the film, she kills herself. Melek, as a word, means "angel" in English, but ironically, she has lived a sinful life full of mistakes and calamities till her death. The reason that Atıf Yilmaz chooses to employ this name could be that Melek is an instinctively good-tempered woman despite all of her mistakes. 
Especially, when Serap gets sick and looks for motherly affection, Melek takes care of her. In some cases, she also assists both Fulya and Serap.

From the early 1990s, some cinematic changes paved the way for modern techniques in the New Turkish cinema of the 2000s. As slightly different from the 1980s, the use of natural and unnatural light - daylight, streetlights, and interior lights, and the increase of indoor shooting were a sign that cinematic techniques were gradually shifting. Compared to the films of the 1980s, the film takes place in a dark and gloomy atmosphere, which could be implicitly related to what kind of conditions the characters live in. Through the colorful lights in nightclubs and household lamps, characters are enlightened in indoor spaces. Though outdoor shooting is rare, the streetlights are employed. The diversity of shots seems to remain nearly the same, yet in some scenes, the use of close-ups is present to emphasize the significance of the scene. For instance, in the scene where Serap puts on red lipstick in the nightclub before leaving with a customer, the camera zooms in on Serap's lips through the close-up shot, thereby putting emphasis on her sexuality. Also, towards the end of the film, there is a scene where Serap obsessively counts money. Here, through the close-up shot, the emphasis is put on money and Serap's state of mind.

Overall, all these social and cinematic codes have contributed to drawing a complete portrait of the representations of women in these two films within the context of gender codes. 
Grounded within a semiotic approach, the analyses have aimed to contextualize gender codes, providing deeper insights into the social and historical background of Turkey, and to advance the knowledge of how films function as a language. One of the most productive filmmakers between the 1980s and the 1990s, Atıf Y1lmaz created a distinctive awareness regarding women and their issues and aimed to narrate women's issues from their perspective in films. Regardless of the social and political milieu of the period and ideological approaches, he always tried to demonstrate their invisible and unknown side, tackling the representation of women in depth. Although the representations of women were constantly shifting from the 1980s through the 1990s, Y1lmaz not only constructed marginalized, independent female characters demanding justice and freedom but also questioned the identity crisis of the women outcast from society and financially desperate. On this basis, while in Y1lmaz's films in the 1980s, women were mostly depicted as those who know what they want and struggle to break down the patriarchal rules to gain sexual freedom and equal rights, in the 1990s there were several representations: an independent woman but all alone, an outcast, and a prostitute, unlike the films based on Islamic ideologies of the 1990s. 


\section{REFERENCES}

Akser, Murat (2016). Changing LGBT Narratives in Turkish Cinema. Reconstruction, 16 (2), 5-7.

Akser M. (2018) Locating Turkish Cinema Between Populist Tendencies and Art Cinema. In: Magnan-Park A., Marchetti G., Tan S. (eds) The Palgrave Handbook of Asian Cinema. Palgrave Macmillan, London. https://doi.org/10.1057/978-1-349-95822-1_8

Arat, Y. (1994) Toward a democratic society: The women's movement in Turkey in the 1980s. Women's Studies International Forum 17(2-3), 241-248.

Arat, Y. and Ş. Pamuk (2019). Turkey between Democracy and Authoritarianism. Cambridge University Press.

Atakav, E. (2013). Women and Turkish Cinema: Gender Politics, Cultural Identity, and Representation. Routledge.

Berger, A. A. (2020). USA Pop. Cambridge Scholars Publishing.

Cengiz, E. P. (2020). Cinema Has Split the Girl's Soul Into Pieces: Scrutinizing Representations of Women in Films From Turkey. International Journal of Communication, 14, 5482-5498.

Dönmez-Colin, G. (2010). Women in Turkish Cinema: Their Presence and Absence as Images and as Image-Makers. Third Text, 24(1), 91-105.

Dönmez-Colin, G. (2004). Women, Islam and Cinema. Reaktion Books Ltd.

Duyan, Y. (2013, May 2-4). 1980 Öncesi Türkiye Sinemasinda Kadın Temsilleri: Adl V Vasfiye Filmi Üzerine Bir Inceleme [Paper Presentation]. II. International Conference on Communication, Media, Technology and Design, Famagusta, North Cyprus.

Eco, U. (1976). A Theory of Semiotics. Indiana UP.

Erdem, A. M. (2019). Ibne, Gey, Lubunya: A Queer Critique of LGBTI+ Discourses in the New Cinema of Turkey. Unpublished MA Thesis, CUNY. 
Foucault, M. (1980). Power/Knowledge: Selected interviews and other writings 1972-1977. (C. Gordon, Ed.). The Harvester Press.

Kaplan, E. A. (2001). Women \& Film: Both Sides of the Camera. Routledge.

Kaya, D., \& Azak, U. (2015). Crossroads (1970) and the origin of Islamic Cinema in Turkey. Historical Journal of Film, Radio and Television, 35(2), 257-276.

Kılıçkıran, C. A. (1997). Women in Turkish Cinema. Insight Turkey, (11), 89-111.

Kuyucak Esen, Ş. (2019). 80’ler Türkiye’sinde Sinema. Su Yayınevi.

Leake, A. (2011). A Brief History of the Feminist Movements in Turkey. https://www.eir.info/2012/08/29/a-brief-history-of-the-feminist-movements-in-turkey/

Özbay, F. (1995). Changes in Women's Activities both Inside and Outside the Home. In Ş. Tekeli (Ed.), Women in Modern Turkish Society: A Reader (pp.89-110). Zed Books.

Samim, A. (1981). The tragedy of the Turkish left. New Left Review, 126(1), 60-85.

Tekeli, Ş. (1981). Women in Turkish politics. In Women in Turkish society (pp. 293-310). Brill.

Wittig, M. (1992). The Straight Mind and Other Essays. Beacon Press.

Zürcher, E. J. (2017). Turkey: A modern history ( $4^{\text {th }}$ ed.). IB Tauris.

\section{ENDNOTES}

${ }^{1}$ Arabesque-themed films are the films which revolve around arabesque music singers' lives and their miserable living conditions. Arabesque singers usually sing the songs about misery, poverty, and destiny. From the 1970s, people started to immigrate to the big cities such as Istanbul, Ankara, and Izmir to find a job and to have better opportunities. At that time, these people had to live in poor conditions. Thus, arabesque music gained popularity 
among immigrant people as they thought that this type of music represented their agony, destiny, poverty, and pessimistic lives (Kuyucak Esen 125-127).

${ }^{2}$ Islamic feminism, which emerged in the 1990s, is a movement that Islamist intellectual women question the place of women in Islam and advocate that Islam allows for women's freedom, justice, and equality in society (Leake 2).

${ }^{3}$ Atıf Y1lmaz (1925-2006) is one of the most renowned Turkish filmmakers of the 1980s. He is best known as the filmmaker of women's films. He actively shot films from the early 1950s to the early 2000s. Most of the films which he shot in the 1980s foreground women's issues and the place of women in society.

${ }^{4}$ Cinematic codes are all the cinematographic elements, including lighting, camera, shot, camera angles, framing, editing, etc. which are used to create cinematic language.

${ }^{5}$ Social/cultural codes are the attributes that belong to a specific location, society, or person. In a film, the analysis of characters relies on the cultural conventions of society where they live. For instance, the behaviours, characteristics, gestures (bodily and facial expressions) are among the social codes of a person/character.

${ }^{6}$ Beyoğlu is a district located in Istanbul and where there are many night clubs and bars.

${ }^{7}$ Adana is a city in Southern Turkey. 